\title{
De wondere wereld van het recht
}

\author{
Citation for published version (APA):
}

Hage, J. C. (2007). De wondere wereld van het recht. Jaap Hage. https://doi.org/10.26481/spe.20070615jh

Document status and date:

Published: 15/06/2007

DOI:

10.26481/spe.20070615jh

Document Version:

Publisher's PDF, also known as Version of record

\section{Please check the document version of this publication:}

- A submitted manuscript is the version of the article upon submission and before peer-review. There can be important differences between the submitted version and the official published version of record.

People interested in the research are advised to contact the author for the final version of the publication, or visit the DOI to the publisher's website.

- The final author version and the galley proof are versions of the publication after peer review.

- The final published version features the final layout of the paper including the volume, issue and page numbers.

Link to publication

\footnotetext{
General rights rights.

- You may freely distribute the URL identifying the publication in the public portal. please follow below link for the End User Agreement:

www.umlib.nl/taverne-license

Take down policy

If you believe that this document breaches copyright please contact us at:

repository@maastrichtuniversity.nl

providing details and we will investigate your claim.
}

Copyright and moral rights for the publications made accessible in the public portal are retained by the authors and/or other copyright owners and it is a condition of accessing publications that users recognise and abide by the legal requirements associated with these

- Users may download and print one copy of any publication from the public portal for the purpose of private study or research.

- You may not further distribute the material or use it for any profit-making activity or commercial gain

If the publication is distributed under the terms of Article $25 \mathrm{fa}$ of the Dutch Copyright Act, indicated by the "Taverne" license above, 
De wondere wereld van het recht 


\section{Colofon}

Ontwerp illustratie omslag: Naoimh Ingram

Ontwerp en print: Océ Business Services, Universiteit Maastricht

ISBN: 978-90-5681-257-7

NUR 820

Alle rechten voorbehouden. Niets uit deze uitgave mag worden verveelvoudigd, opgeslagen in een geautomatiseerd gegevensbestand of openbaar gemaakt, zonder voorafgaande schriftelijke toestemming van de auteur of uitgever. 


\section{De wondere wereld van het recht}

Rede

in aangepaste vorm uitgesproken bij de aanvaarding van het ambt van hoogleraar Algemene rechtsleer aan de Faculteit der Rechtsgeleerdheid van de Universiteit Maastricht

op vrijdag 15 juni 2007

door

Jaap C. Hage

U

MU Universiteit Maastricht

30 YEARS OF INTERNATIONAL OUALITY 

In view of the exceedingly important role the use of concepts of various kinds plays in the law it is undoubtedly a trifle surprising that within jurisprudence the question of the functions of legal concept formation in general has been subjected to so little analysis. ${ }^{1}$

Mijnheer de Rector, overige gewaardeerde toehoorders.

\section{De wondere wereld van het recht}

Juristen leven in een wonderbaarlijke wereld; ze hebben het alleen vaak zelf niet door. Teneinde het inzicht in de wondere wereld van het recht een beetje groter te maken, stel ik voor dat we ons even in een andere wereld verdiepen en wel in de sprookjeswereld van 1001 nacht. Eén van die sprookjes is het verhaal van Ali Baba en de veertig rovers. Ali Baba is een arme houthakker en op een dag is hij in het bos aan het werk. In de verte ziet hij een grote stofwolk oprijzen die langzaam dichterbij komt. Veiligheidshalve klimt Ali Baba in een boom om zich te verschuilen. Het is maar goed ook dat hij dat deed, want als de stofwolk dichterbij is gekomen en uiteindelijk is gaan liggen, ziet Ali Baba dat het om een bende van veertig bereden rovers gaat, die hun buit bij zich dragen. De rovers stoppen aan de voet van een hoge rots en de roverhoofdman spreekt de beroemd geworden woorden 'Sesam, open u!'. Op deze woorden van de roverhoofdman opent de rots zich en de rovers gaan naar binnen om hun buit op te bergen. Een tijdje later komen de rovers weer naar buiten en de rots sluit vanzelf weer.

Ali Baba wacht tot de rovers verdwenen zijn. Hij opent de rots door het uitspreken van de toverformule en neemt een deel van de enorme schatten die binnen de rots verborgen liggen mee naar huis. Er volgen dan nog vele avonturen en als $u$ die niet kent, raad ik $u$ aan om het verhaal nog eens te lezen. Het staat tegenwoordig gewoon op het internet. ${ }^{2}$ Vandaag moeten we ons echter met serieuze zaken bezig houden. Dat is nu de kwestie hoe het mogelijk is om enkel door het uitspreken van woorden, zoals 'Sesam, open u!' de wereld te veranderen.

We weten allemaal dat sprookjes, net als dromen, bedrog zijn. In sprookjes kan er van alles gebeuren dat in het echt niet kan. Bijvoorbeeld rotsen openen, niet met behulp van dynamiet, maar enkel door het uitspreken van de juiste toverspreuk. Zoiets kan enkel in een sprookjeswereld. Hoewel ... in de wondere wereld van het recht is ook van alles mogelijk. 
Neem nu Mark en Tineke. Ze staan in het gemeentehuis naast elkaar en tegenover de ambtenaar van de burgerlijke stand. Beiden beantwoorden ze een vraag van de ambtenaar door het uitspreken van de toverspreuk 'ja'. De ambtenaar spreekt ook een toverspreuk uit en van het ene moment op het andere zijn Tineke en Mark gehuwd, met alle gevolgen van dien.

Als ik de gebeurtenissen op deze manier beschrijf, zullen velen onder $u$ - en dan vooral de juristen - misschien hoofdschuddend zitten te luisteren. Er is immers niets bijzonders aan de hand. Tineke en Mark zijn gewoon getrouwd. Hun jawoord markeerde de daarvoor benodigde wilsovereenstemming en de ambtenaar kon daardoor de zin uitspreken waarmee het burgerlijk huwelijk werd voltrokken. Een gewone rechthandeling, zoals het recht er zoveel kent. In de sfeer van het privaatrecht bijvoorbeeld het sluiten van overeenkomsten en het maken van testamenten. In de sfeer van het publiekrecht wetgeving, het verlenen van vergunningen en besluiten van de officier van justitie om strafzaken te seponeren. De macht van de juridische gewoonte maakt dat we de wonderen in de wereld van het recht niet meer zien. En over wat we niet zien denken we niet na. Maar nu, wakker geschud door Ali Baba, kunnen we onze ogen niet meer sluiten voor de wonderen in de wereld van het recht. Nu moeten we ons afvragen hoe rechtshandelingen mogelijk zijn.

\section{Het belang van algemene begrippen}

De belangstelling van juristen voor het recht is meestal gericht op één van twee vragen: 'Hoe luidt het recht?' en 'Wat is een goede regeling voor deze kwestie?'. De algemene begrippen van het recht, zoals 'subjectief recht', 'rechtsplicht' en 'rechtshandeling' worden in verhandelingen over het recht wel besproken - meestal in inleidende boeken of paragrafen - maar mogen zich in het algemeen toch in minder belangstelling verheugen dan de twee genoemde vragen. Ten onrechte. De algemene begrippen vormen als het ware de bouwstenen waarmee het bouwwerk van het recht is opgetrokken. Zonder kennis over deze bouwstenen is inzicht in wat daarmee is gebouwd oppervlakkig. ${ }^{3}$

Ik zal hier ingaan op één van de algemene begrippen van het recht in Europa (en daarbuiten), te weten de rechtshandeling. Over de rechtshandeling is alleen al in Nederland een grote hoeveelheid literatuur verschenen, maar zoals ik nog zal betogen gaat het merendeel van die literatuur niet over de vraag wat een rechtshandeling is, maar over de 
vraag wanneer er sprake is van een geldige rechtshandeling. Deze laatste vraag gaat over de traditionele kwesties hoe het positieve recht luidt, of zou moeten luiden; de eerste heeft nog weinig aandacht gekregen. ${ }^{4}$

Bij rechtsvergelijking is kennis over de algemene begrippen van het recht essentieel. Juist door hun algemene karakter kunnen algemene begrippen de kern uitmaken van een begrippenkader dat de nationale rechtssystemen overstijgt en dat kan fungeren als het tertium comparationis dat noodzakelijk is voor rechtsvergelijking. ${ }^{5}$ Dit geldt zowel voor externe rechtsvergelijking, waarbij verschillende rechtssystemen met elkaar worden vergeleken, als voor interne rechtsvergelijking, waarbij verschillende delen van één systeem naast elkaar worden gelegd. Zo is het mogelijk om de rol van rechtshandelingen in het Engelse en het Nederlandse recht te vergelijken, maar ook om het functioneren van rechtshandelingen binnen het privaatrecht, het staatsrecht en het bestuursrecht met elkaar te vergelijken.

Sommigen zullen misschien bezwaar maken tegen de suggestie dat in het Engelse recht rechtshandelingen zouden voorkomen. Als het Engelse recht de rechtshandeling niet kent, hoe is het dan mogelijk om rechtshandelingen in het Engelse en het Nederlandse recht te vergelijken? Een dergelijk bezwaar berust mijns inziens op het door elkaar halen van begrippen die worden gebruikt in het recht en begrippen die een rol spelen binnen het recht. ${ }^{6}$ Het komt in het recht regelmatig voor dat regelgeving als het ware uit een tweetrapsraket bestaat. ${ }^{7}$ Eerst is er een regeling die aangeeft wanneer een bepaald begrip van toepassing is en dan een regeling die rechtsgevolgen verbindt aan de toepasselijkheid van dit begrip. Een mooi voorbeeld van een dergelijke constructie vinden we in de Principles of European Contract Law. ${ }^{8}$ Eerst wordt uitgelegd (in hoofdstuk 2) wanneer een contract tot stand komt; daarna (in de hoofdstukken 6 en 7) wordt aangegeven welke verplichtingen ontstaan als er een contract is. Uit deze regelingen blijkt dat het begrip contract niet alleen een rol speelt binnen, maar ook wordt gebruikt in het recht volgens de Principles. De Principles bevatten regelingen waarin het expliciet gaat over (een soort) rechtshandelingen.

Het begrip 'rechtshandeling' wordt niet gebruikt in het Engelse recht, maar de verschijnselen die in het Nederlandse recht als rechtshandelingen worden aangeduid, doen zich in het Engelse recht ook voor. Ook aan de overzijde van de Noordzee is het mogelijk om testamenten te maken en om contracten af te sluiten en ook daar is het intreden van de rechtsgevolgen in deze gevallen in beginsel afhankelijk van de vraag of ze werden beoogd. Dit wil zeggen dat het begrip rechtshandeling 
een rol speelt binnen het Engelse recht. Dat er geen abstract leerstuk 'rechtshandeling' wordt gebruikt om deze gevallen onder dezelfde regeling te laten vallen doet daar niet aan af. Als ons inzicht in de aard van rechtshandelingen in het algemeen - dus los van of en hoe ze precies in een bepaald rechtssysteem worden geregeld - verdiept, groeit daarmee dus ook het inzicht in het recht van systemen waarin het begrip 'rechtshandeling' niet wordt gebruikt.

Deze bijdrage is gewijd aan een analyse van rechtshandelingen die abstraheert van de implementatie van rechtshandelingen binnen verschillende rechtssystemen. Het is me er bijvoorbeeld niet om te doen onder welke omstandigheden een rechtshandeling tot stand kan komen op grond van vertrouwen, onder welke omstandigheden 'gebreken' in de wil van de handelende persoon (in het vervolg: de rechtshandelaar) de geldigheid van een rechtshandeling aantasten, of wat precies de rechtsgevolgen zijn van een geldige rechtshandeling. Al deze kwesties zijn van groot belang voor het positieve recht, maar van minder betekenis voor de vraag wat een rechtshandeling is.

Nu kan men zich de vraag stellen wat het nut is van zo'n algemene theorie over rechtshandelingen, als al deze belangrijke onderwerpen daarin niet aan de orde komen. Deze vraag kan pas goed beantwoord worden op grond van de theorie over rechtshandelingen die nog geformuleerd moet worden. Daarop vooruitlopend luidt het voorlopige antwoord dat inzicht in de aard van rechtshandelingen het begrip van het recht dat, al dan niet expliciet, gebruik maakt van rechtshandelingen, vergroot, rechtsvergelijking vereenvoudigt, en discussies over hoe rechtshandelingen geregeld moeten worden verheldert. Het valt te vergelijken met de kennis van een muziekinstrument, bijvoorbeeld een klarinet. Als je weet wat een klarinet is, begrijp je muziekstukken waarin een klarinet wordt gebruikt beter en wordt het eenvoudiger om de rol van klarinetten binnen verschillende composities te vergelijken en om composities met klarinetten te schrijven.

Een belangrijke theorie over de aard van rechtshandelingen is de zogenaamde 'wilstheorie'. In het navolgende laat ik eerst zien welke vooronderstellingen door de klassieke wilstheorie worden gemaakt ten aanzien van de aard van het recht, om vervolgens te betogen dat in het licht van deze vooronderstellingen de wilstheorie beter kan worden vervangen door de taalhandelingstheorie. Deze taalhandelingstheorie wordt uitgewerkt en leidt tot de conclusie dat rechtshandelingen middelen zijn om de 'wereld van het recht' intentioneel te veranderen. Hiermee is de analyse van wat rechtshandelingen zijn afgesloten, maar 
de vraag hoe deze analyse zich verhoudt tot de regelingen van rechtshandelingen in het positieve recht is daarmee nog niet beantwoord. Het blijkt dat die regelingen veelal rechtshandelingen aannemen waar die er strikt genomen niet zijn en aan rechtshandelingen rechtsgevolgen toekennen die de handelende personen daarmee niet beoogden te bewerkstelligen. Het slot van de bijdrage is gewijd aan beschouwingen hoe deze discrepantie tussen wat rechtshandelingen eigenlijk zijn en de rol die ze feitelijk binnen het positieve recht spelen, kan worden opgeheven.

\section{De wilstheorie}

Eén manier om tegen rechtshandelingen aan te kijken is alsof het een soort wetgeving is. ${ }^{9}$ Net zoals de wetgever nieuw recht in het leven roept en oud recht afschaft, zo schept een rechtshandelaar nieuwe rechtsverhoudingen en beëindigt oude rechtsverhoudingen. En zoals het regelgevend vermogen van de wetgever verbonden wordt met diens soevereiniteit, wordt het vermogen om rechtshandelingen te verrichten gezien als uitvloeisel van de individuele autonomie. Zo schrijft Meijers:

'Bij de rechtshandelingen beweegt men zich ... op het gebied, waarop de individuen autonomie toekomt, d.w.z. waarop zij voor zichzelf of anderen rechtsgevolgen in het leven roepen. Het rechtsgevolg treedt bij de rechtshandeling in, omdat de handelende personen dit willen.' ${ }^{10}$

In Duitsland schrijven Larenz en Wolf:

'... dass der Wille als Ausfluss und Ergebnis einer privatautonomen Entscheidung verstanden werden muss, deren Umsetzung in rechtlich bindende Folgen der Willenserklärung dient. Wenn der rechtsgeschäftliche Wille die privatautonomen Willensinhalte wiedergeben soll, dann müssen diese Willensinhalte auch als Ausdruck autonomer Entscheidungsfreiheit erscheinen, ...'11

En Ghestin in Frankrijk schrijft over deze opvatting (toegespitst op het sluiten van een overeenkomst):

'Selon la théorie de l'autonomie de la volonté l'homme étant libre par essence ne peut s'obliger que par sa propre volonté. II en résulte que la volonté qui, indépendamment de la loi, en tant que source du droit unique et autonome, crée les effets du contrat et en détermine 
le contenu de façon souveraine. Ces effets juridiques n'existent que parce que ils ont été voulu et comme ils ont été voulu. ${ }^{12}$

Vanzelfsprekend is de wil alleen niet voldoende om rechtsgevolgen in het leven te roepen. Het maatschappelijk verkeer verlangt dat rechtsgevolgen kenbaar zijn en daarmee ook dat gebeurtenissen die tot rechtsgevolgen leiden als zodanig herkend kunnen worden. Vandaar het vereiste dat de wil tot uitdrukking moet komen in een verklaring. Het is echter de wil die in de wilstheorie centraal staat, niet de verklaring. Dit komt goed tot uitdrukking in de formulering van Von Savigny:

'Jedoch ist dieses (d.h. das Verhältnis von Wille und Erklärung) nicht zu verstehen als ob beide ihrer Natur nach unabhängig voneinander wären, .. ; vielmehr sinds sie schon ihrem Wesen nach als verbunden zu denken. Denn eigentlich muss der Wille an sich als das einzige Wichtige und Wirksame gedacht werden, und nur weil er ein inneres, unsichtbares Ereignis ist, bedürfen wir eines Zeichen, wodurch sich der Wille offenbart, ist eben der Erklärung.'13

De centrale rol van de wil komt ook tot uitdrukking in de betekenis die wordt toegekend aan het ontbreken van de wil (discrepantie tussen wil en verklaring), en aan rechtshandelingen gebaseerd op een onzuiver tot stand gekomen wil (geestelijke stoornis en de klassieke wilsgebreken). Dat deze verschijnselen aanleiding hebben gegeven tot volledige leerstukken in verband met de rechtshandeling valt te verklaren vanuit de centrale rol die de wil speelt in onze opvatting van rechtshandelingen.

Wat zijn nu de implicaties van de wilstheorie voor de rechtsgevolgen van een rechtshandeling? Afgaande op wat Meijers en Ghestin schreven, namelijk dat bij rechtshandelingen de rechtsgevolgen intreden omdat partijen dit willen, impliceert de wilstheorie dat slechts door partijen beoogde (gewilde) rechtsgevolgen intreden als gevolg van de rechtshandeling. Teneinde deze rechtsgevolgen te kunnen vaststellen is het dus van belang na te gaan wat de rechtshandelaar wilde toen hij de rechtshandeling verrichtte. Van Dunné heeft het in dit verband treffend over de historisch-psychologische uitleg van rechtshandelingen. ${ }^{14}$ Omdat de wil opgemaakt moet worden uit feitelijke gebeurtenissen, vindt bij deze uitleg noodgedwongen een zekere mate van objectivering plaats, maar deze objectivering mag niet zo ver gaan dat de historische wil, voor zover kenbaar, opzij gezet wordt ten behoeve van een 'sociale wilsorde'15 of de goede trouw. ${ }^{16}$ 
Volgens de wilstheorie kan er slechts sprake zijn van een rechtshandeling ${ }^{17}$ als de handelende persoon de wil had om door middel van zijn handeling bepaalde rechtsgevolgen in het leven te roepen en als de rechtsgevolgen samenvallen met hetgeen door de handelende persoon werd beoogd, of daar tenminste een deel van uit maken. ${ }^{18}$ De wil is volgens de wilstheorie dus zowel een bestaansvoorwaarde voor de rechtshandeling als voor de rechtsgevolgen.

\section{De wil die de werkelijkheid verandert}

Dat de wil zo'n centrale rol kan spelen bij het tot stand brengen van rechtsgevolgen, is een verschijnsel dat speciale aandacht verdient. Het is niet vanzelfsprekend dat men door middel van zijn wil de feiten kan veranderen. Voor wat fysische feiten betreft is dat ook geheel onmogelijk; afgezien van sprookjesfiguren is niemand er ooit in geslaagd enkel door middel van een wilsverklaring een berg te doen splijten. Bij de sociale werkelijkheid ligt dat ten dele anders. Anders dan de fysieke werkelijkheid is de sociale werkelijkheid afhankelijk van wat wij denken dat die is. Het bestaan van geld is daar een sprekend voorbeeld van. Bepaalde stukken papier kunnen in een eenvoudige samenleving enkel als geld fungeren, en dus geld zijn, als ze als geld worden erkend. Als bijna iedereen het er over eens is dat bepaalde stukken papier geld zijn, dan zijn die stukken papier ook geld. ${ }^{19}$ Voor ongeschreven recht geldt iets vergelijkbaars. Als voldoende relevante ${ }^{20}$ personen denken dat een bepaalde ongeschreven norm een rechtsnorm is, dan is het ook een rechtsnorm. Het is in dit verband overigens wel essentieel dat er voldoende relevante personen zijn die bepaalde feiten erkennen als deel van de sociale werkelijkheid. Eén individu zal normaal gesproken niet in staat zijn de sociale werkelijkheid te bepalen door middel van erkenning. Wat dit betreft is de sociale werkelijkheid niet anders dan de fysieke werkelijkheid: de feiten zijn onafhankelijk van wat een individueel mens denkt dat ze zijn. Het verschil zit in de aantallen. De fysieke werkelijkheid is onafhankelijk van de mening van hoeveel mensen dan ook ${ }^{21}$; de sociale werkelijkheid verandert als voldoende mensen van mening veranderen over wat die inhoudt. Als bijvoorbeeld iedereen denkt dat een bepaalde norm een rechtsnorm is, dan is het normaal gesproken ook een rechtsnorm.

Nu zou men kunnen tegenwerpen dat de kwestie wat geld is tegenwoordig bij wet wordt geregeld en dat het merendeel, namelijk het geschreven deel, van het recht ook door middel van de wet wordt vastgesteld. Dat klopt en het illustreert dat bepaalde delen van de sociale 
werkelijkheid geïnstitutionaliseerd zijn. Daarmee bedoel ik dat er regels zijn die bepalen hoe bepaalde onderdelen van de sociale werkelijkheid er uit zien. ${ }^{22}$ De sociale werkelijkheid is dan niet wat 'men' er van denkt, maar wat de regels zeggen dat die is. Een interessante bijkomstigheid in dit verband is dat het bestaan van die regels zelf ook weer een deel van de geïnstitutionaliseerde sociale werkelijkheid is. De rechtsregels die bepalen wat geld is, zijn zelf regels van geschreven recht, die gelden omdat er andere regels zijn die bepalen dat wetten in formele zin geldend recht zijn. ${ }^{23}$

Niet alleen regels kunnen een onderdeel zijn van de geïnstitutionaliseerde werkelijkheid; individuele verplichtingen kunnen daar ook toe behoren. ${ }^{24}$ Als een belastinginspecteur een aanslag oplegt, ontstaat daardoor een verplichting tot betaling. Daartoe is niet vereist dat die verplichting alom erkend wordt; het bestaan van de relevante regel die de belastinginspecteur bevoegd maakt om aanslagen op te leggen is daartoe voldoende. ${ }^{25}$

Opvallend is dat waar de 'gewone' sociale werkelijkheid niet afhankelijk is van de wil van individuele personen, de geïnstitutionaliseerde werkelijkheid dat wel kan zijn. Het volstaat daartoe dat er een regel is die de betreffende afhankelijkheid tot stand brengt, bijvoorbeeld door iemand bevoegd te maken om door middel van zijn wil nieuwe institutionele feiten tot stand te brengen. Omwille van de sociale effectiviteit zullen de institutionele gevolgen - nog steeds volgens de wilstheorie - afhankelijk worden gemaakt van de wilsuiting, niet van de wil alleen, maar dat doet er niet aan af dat in een institutionele setting, anders dan in een 'gewone' sociale setting, de wil van individuen bepalend kan zijn voor de feiten.

Met het voorbeeld van de belastinginspecteur zijn we inmiddels onmiskenbaar beland in de sfeer van de rechtshandelingen. Dat het mogelijk is om door middel van de wil veranderingen tot stand te brengen in de rechtswerkelijkheid, komt omdat de rechtswerkelijkheid ten dele een geïnstitutionaliseerde werkelijkheid is. ${ }^{26}$ Dat maakt namelijk dat de feiten van het recht afhankelijk kunnen zijn van de wil van individuen. De wilstheorie over rechtshandelingen is dan ook impliciet gebaseerd op de aanname dat de rechtswerkelijkheid geïnstitutionaliseerd is. Het is evenwel de vraag of de deze theorie de beste karakterisering geeft van de aard van rechtshandelingen, als wordt uitgegaan van de rechtswerkelijkheid als (ten dele) geïnstitutionaliseerd. De interpretatie van rechtshandelingen als een soort taalhandelingen zou die aanname wel eens beter kunnen representeren. 


\section{Taalhandelingstheorie}

In zijn proefschrift, Drie beginselen van contractenrecht, stelt Nieuwenhuis voor om de overeenkomst te beschouwen als een taalhandeling. Hoewel de wil bij taalhandelingen nog steeds van belang is (Nieuwenhuis ziet niet voor niets het autonomiebeginsel als één van de drie beginselen van het contractenrecht), komt de nadruk in deze visie verhoudingsgewijs meer te liggen op de uiting van de wil in de wilsverklaring. Zoals we nog zullen zien, sluit de interpretatie van rechtshandelingen als een soort taalhandelingen uitstekend aan bij de aanname dat de rechtswerkelijkheid in belangrijke mate een geïnstitutionaliseerde werkelijkheid is. Deze aanname is cruciaal voor de wilstheorie, maar als de taalhandelingtheorie, de opvatting dat rechtshandelingen het best kunnen worden gezien als een speciale categorie van taalhandelingen, nog beter aansluit bij deze aanname, valt er wat voor te zeggen om de wilstheorie te vervangen door de taalhandelingstheorie.

Het beginpunt van de taalhandelingstheorie is het inzicht, met kracht naar voren gebracht door John Longshaw Austin (de $20^{\text {ste }}$ eeuwse taalfilosoof, niet de $19^{\mathrm{e}}$-eeuwse Engelse rechtspositivist) dat taal niet alleen kan worden gebruikt om beweringen te doen, maar ook om allerlei andere soorten handelingen, taalhandelingen, te verrichten. ${ }^{27}$ Zo zal de persoon die een fles wijn tegen een schip kapot gooit en daarbij de woorden uitspreekt 'Ik doop u de Anna Jacoba' normaal gesproken niet de intentie hebben zijn eigen gedrag te beschrijven (een bewering over zichzelf), maar om door het uitspreken van die woorden te doen wat hij zegt te doen, namelijk het dopen van het schip.

Austin's theorie over taalhandelingen werd substantieel uitgebreid door zijn leerling John Searle in diens boek Speech Acts en in latere artikelen. ${ }^{28}$ Een belangrijk onderdeel van Searle's theorie is dat aan een taalhandeling twee aspecten kunnen worden onderscheiden, namelijk de propositionele inhoud en de illocutionaire strekking. Elke handeling is een handeling van een bepaalde soort ${ }^{29}$ zoals bewegen van een vinger, rekenen en dopen. Binnen die ruime categorie van handelingen is er een belangrijke subcategorie van handelingen met een zogenaamde 'propositionele inhoud'. Dit zijn handelingen die ergens over gaan en de propositionele inhoud geeft aan waar de handeling over gaat. ${ }^{30}$ Een propositie is hetgeen wordt uitgedrukt door een zin. Zo drukken de Duitse zin 'Es regnet' en de Engelse zin 'It's raining' dezelfde propositie uit, namelijk dat het regent. Omdat proposities nauw verbonden zijn aan taal, zij het niet aan een specifieke taal, hebben handelingen met een propositionele inhoud steeds iets met taal te maken en dat verklaart waarom ze als 'taalhandelingen' worden aangeduid. 
Stel dat een vader met zijn dochtertje aan het wandelen is en de gelegenheid aangrijpt om haar te leren welke honden gevaarlijk zijn. Ze zien bijvoorbeeld twee honden lopen, allebei op afstand en veilig aangelijnd, en hij zegt 'Die grote hond daar (een Sint Bernard) is ongevaarlijk, maar dat kleintje met die brede bek (een pitbullterriër), die is gevaarlijk'. Met het uitspreken van die woorden beoogt de vader zijn dochter enkel maar informatie te geven, want in de concrete omstandigheden dreigt er geen enkel gevaar. De inhoud van deze informatie - dat de kleine hond gevaarlijk is (en de grote niet) - is de propositionele inhoud van de mededeling. Maar in andere omstandigheden, bijvoorbeeld als een kleine hond met brede bek met de nekharen overeind grommend komt aanrennen, is het uitspreken van de zin 'Die hond is gevaarlijk' niet (primair) het verschaffen van informatie, maar het uiten van een waarschuwing. In beide gevallen is de propositionele inhoud, waar de taalhandeling over gaat, hetzelfde, namelijk het gevaarlijk zijn van de kleine hond, maar in het eerste geval gaat het om een bewering waarmee informatie wordt verschaft en in het tweede geval gaat het om een waarschuwing. Het doen van een bewering en het geven van een waarschuwing zijn handelingen met een verschillende illocutionaire strekking, die in dit voorbeeld dezelfde propositionele inhoud hebben. Een ander voorbeeld is het uitspreken van de zin 'Mijnheer Jansen is de voorzitter' die weer kan dienen als beweerzin, maar ook als het benoemen van mijnheer Jansen tot voorzitter. Een juridisch voorbeeld is dat het uitspreken van de zin 'Ik wil je fiets wel kopen voor $€$ 100,-', kan dienen als zelfbeschrijving, maar ook als het doen van een aanbod.

Zoals uit deze voorbeelden blijkt, geeft de propositionele inhoud van een taalhandeling wel aan waar de handeling over gaat, maar niet om wat voor soort handeling het gaat. De soort van de handeling wordt bij taalhandelingen aangegeven door de illocutionaire strekking. Deze strekking is bijvoorbeeld dat het gaat om het dopen van een kind, het uitloven van een beloning, het uitgeven van een persbericht, het maken van reclame, of het verschaffen van informatie. Er zijn vele manieren waarop de illocutionaire strekking van een taalhandeling tot uitdrukking kan worden gebracht, zoals het gebruik van leestekens of toonhoogte. De context speelt hierbij een belangrijke rol.

De propositionele inhoud van een taalhandeling is datgene dat al dan niet correspondeert met de feiten. Een belangrijk inzicht in dit verband is dat die correspondentie twee richtingen kan hebben. ${ }^{31} \mathrm{Bij}$ beweringen is het de bedoeling dat hetgeen dat wordt beweerd, de propositionele inhoud, correspondeert met de feiten. Met andere woorden, 
de (oprechte) spreker pretendeert dat wat wordt beweerd inderdaad het geval is. In dergelijke gevallen heeft Searle het over correspondentie van de woorden met de wereld (word to world direction of fit). Bij bevelen is het juist andersom. Als een korporaal een soldaat beveelt om rechtsomkeert te maken, is het niet zijn bedoeling een ware beschrijving te geven van het gedrag van de soldaat, maar juist dat de soldaat zijn gedrag richt naar wat hij beveelt. Het gaat dan om correspondentie van de wereld met de woorden (world to word direction of fit).

De richting van de correspondentie kan worden gebruikt om onderscheid te maken tussen verschillende categorieën van taalhandelingen. In zijn artikel A Taxonomy of Illocutionary Acts onderscheidt Searle vijf hoofdsoorten taalhandelingen:

- Beweringen (assertives), die de spreker eraan committeren dat iets het geval is. Beweringen beogen dat de woorden corresponderen met de wereld. Een bewering is succesvol (waar) als het beweerde overeenstemt met de feiten, zoals het geval zou zijn bij mijn bewering 'lk draag een bril'.

- Opdrachten in ruime zin (directives), pogingen van de spreker om de toehoorder ertoe te bewegen iets te doen (of na te laten). Opdrachten beogen correspondentie van de wereld met de woorden teweeg te brengen. ('Laten wij bidden.') Een opdracht is dan ook succesvol (effectief) als de feiten, met name het gedrag van de toehoorder, in overeenstemming zijn met het opgedragene.

- Zelfbindingen (commissives), die de spreker verplichten tot bepaald gedrag. Beloften zijn hiervan het standaardvoorbeeld. ('Ik zal mijn openbare rede na 45 minuten afronden.') Ook voor zelfbindingen geldt dat ze beogen de wereld met de woorden te laten corresponderen. Een zelfbinding is volgens Searle succesvol (effectief) als de spreker het toegezegde gedrag waar maakt.

- Verklaringen (declaratives), die een overeenstemming tot stand brengen tussen hetgeen verklaard wordt en de werkelijkheid. Het uitspreken van de zin 'Ik geef je hierbij mijn auto' zou een voorbeeld van zo'n verklaring zijn. Bij een succesvolle (geldige) verklaring wordt de werkelijkheid inderdaad zoals werd verklaard. Het gaat dan ook om de correspondentie van de wereld met de woorden.32

- Gemoedsuitingen (expressives), waarbij de spreker uitdrukking geeft aan zijn gemoedstoestand. Te denken valt bijvoorbeeld aan uitingen van dankbaarheid. Bij gemoedsuitingen wordt er geen correspondentie tussen woorden en wereld beoogd. Ze zijn dan ook enkel uitingen, geen zelfbeschrijvingen. 
Ten aanzien van de correspondentie van de wereld met de woorden is Searle overigens dubbelzinnig. Als de korporaal de soldaat een bevel geeft, is het directe gevolg daarvan dat de soldaat de plicht heeft gekregen om het bevolene uit te voeren. Het mogelijke gevolg van die verplichting en dus het indirecte gevolg van het bevel is dat de soldaat de plicht vervult en rechtsomkeert maakt. Dat de soldaat rechtsomkeert maakt, het indirecte gevolg, is een verandering in de fysieke werkelijkheid. Zoals Searle het presenteert, zou dit indirecte gevolg de aanpassing van de wereld aan de woorden zijn. Meer correct lijkt evenwel de opvatting dat het ontstaan van de plicht, het directe gevolg is van het bevel. Dit is een verandering in de sociale werkelijkheid.

Maar het is ook mogelijk dat taalhandelingen directe gevolgen in de fysieke werkelijkheid beogen en teweeg brengen. Het bevel van de korporaal leidde slechts tot een plicht, omdat de korporaal bevoegd was tot het geven van bevelen. Maar ook zonder bevoegdheid kan men opdrachten geven en die zijn vaak effectief, zelfs al leiden ze niet tot het ontstaan van een plicht. Dan beoogt het bevel een aanpassing van de fysieke werkelijkheid zonder een tussenliggende verandering in de sociale werkelijkheid.

We kunnen dus, in afwijking van Searle, onderscheiden tussen twee soorten correspondentie van de werkelijkheid met de woorden, namelijk correspondentie van de fysieke werkelijkheid met - in het algemeen - de propositionele inhoud van bevelen en correspondentie van de sociale werkelijkheid en met name het geïnstitutionaliseerde deel daarvan, met de propositionele inhoud van verklaringen.

Van de vijf door Searle genoemde hoofdsoorten van taalhandelingen lijken de zelfbindingen en de verklaringen het meest interessant voor vermogensrechtelijke rechtshandelingen. 33 Alvorens verder te gaan, wil ik een afwijking introduceren van de door Searle gehanteerde terminologie. ${ }^{34}$ Searle's verklaringen (declaratives), zijn taalhandelingen waardoor feiten worden gecreëerd, veranderd, of opgeheven. Er wordt bijvoorbeeld iemand tot voorzitter gemaakt, van zijn verplichtingen ontslagen, of een schip krijgt een andere naam. Dat wordt beter tot uitdrukking gebracht door die taalhandelingen constitutieve handelingen, of kortweg constitutieven te noemen. Het constitueren is dan niet perse creatief, maar kan ook inhouden dat bepaalde feiten veranderen of teniet worden gedaan.

Een tweede aanpassing die ik zou willen maken is om zelfbindingen onder te brengen bij de constitutieven. Als iemand een belofte doet, is het weliswaar de bedoeling dat hij in de toekomst het gedrag zal 
vertonen dat hij nu belooft te zullen verrichten, maar dat is slechts een indirect effect van het doen van een belofte. Het directe effect is dat degene die een succesvolle (nu in de zin van geldige) belofte doet, onder de verplichting komt om datgene te doen dat hij beloofde te zullen doen (of nalaten). Met andere woorden, het doen van een belofte is een manier om een verplichting in het leven te roepen. Dat is een constitutieve taalhandeling.

Met deze tweede aanpassing blijkt nog slechts één categorie vaan taalhandelingen relevant te zijn voor de analyse van rechtshandelingen, namelijk de constitutieven. De voor ons relevante theorie is dan ook dat rechtshandelingen een speciale juridische variant zijn op de constitutieve taalhandelingen.

\section{Rechtshandelingen als taalhandelingen}

De taalhandeling is belangrijk als begripsmatig hulpmiddel om de rechtshandeling te begrijpen, omdat hij het handelingskarakter van constitutieven en dus ook van rechtshandelingen benadrukt. Een rechtshandeling moge in zekere zin een wilsverklaring zijn, de opvatting dat een rechtshandeling primair een verklaring is over wat de actor wil, is onjuist. Een rechtshandeling is handeling waarmee bepaalde rechtsgevolgen worden beoogd en ook bewerkstelligd. Maar wat is dan de rol van de wil bij de rechtshandeling?

Ter beantwoording van deze vraag loont het de moeite nog wat aandacht te besteden aan Searle's analyse van taalhandelingen. In zijn boek speech Acts analyseert Searle bij wijze van voorbeeld de belofte en komt daarbij tot een lijst van negen vereisten waaraan voldaan moet zijn wil er sprake zijn van een normale belofte. 35 Niet alle onderdelen van die lijst zijn hier van even groot belang, maar op enkele onderdelen wil ik toch de aandacht vestigen.

Eén vereiste voor het beloven is dat degene die belooft van plan is het beloofde te doen. Dus als Piet serieus aan Maartje belooft haar fiets te zullen repareren, moet Piet van plan zijn om de fiets inderdaad te repareren. Hier zien we iets terug van de wil: Piet wil de fiets repareren en de belofte bevestigt als het ware die intentie. Maar is de intentie om de fiets te repareren echt waar het om gaat bij het doen van deze belofte. Is het niet veeleer de intentie om de verplichting op zich te nemen de fiets te repareren $?^{36}$ Het effect van de belofte is niet zozeer dat Piet de fiets repareert, althans dat is niet het directe effect. Het directe effect is dat Piet de verplichting krijgt om de fiets te repareren. Als Piet die verplichting 
nakomt, repareert hij ook echt de fiets, maar dat is meer het gevolg van de verplichting, dan van de wijze waarop de verplichting ontstond.

Als het directe effect van een belofte is dat de verplichting ontstaat om het beloofde te doen, is dan niet de oprechte intentie om die verplichting te doen ontstaan wezenlijk? Dat is ook de opvatting van Searle, want als nader vereiste voor het doen van een belofte noemt hij de intentie van degene die de belofte doet dat de belofte hem verplicht om te doen wat hij beloofde. Dit is een dubbele intentie: enerzijds wil de spreker dat er een verplichting ontstaat en anderzijds wil hij dat deze verplichting wordt bewerkstelligd door het doen van de belofte. Verder schrijft Searle nog dat deze (dubbele) intentie samenhangt met de essentie van het beloven. Die essentie is namelijk dat beloven het op zich nemen is van een verplichting om een bepaalde handeling (dat mag ook een nalaten zijn) te verrichten.

We zien hier ook de correspondentie terug van de wereld met de woorden, de correspondentie die volgens Searle kenmerkend is voor constitutieven. Of eigenlijk zien we een correspondentie tussen wat wordt beoogd (het doen ontstaan van een verplichting) en de wereld (het feitelijk ontstaan van de beoogde verplichting). Om hetzelfde in juristentaal te zeggen: het rechtsgevolg stemt overeen met hetgeen gewild werd.

Is het dan toch de wil die via de taalhandeling in werkelijkheid wordt omgezet? Nee, een dergelijke nadruk op de wil zou misleidend zijn. Het is de handeling die telt en die het rechtsgevolg meebrengt. De intentie (wil) om het rechtsgevolg te bewerkstelligen is een combinatie van de intentie waarmee de handeling wordt verricht en de propositionele inhoud van die handeling, niet minder, maar ook niet meer. Het belang van de handeling, van het naar buiten toe optreden, wordt ook benadrukt in een derde vereiste dat Searle formuleert voor taalhandelingen en in het bijzonder voor beloften. Door het doen van de belofte beoogt (intendeert) degene die belooft bij degene tot wie de belofte is gericht de wetenschap op te roepen dat het doen van de belofte geldt als het op zich nemen van een verplichting. ${ }^{37} \mathrm{Of}$, om het eenvoudiger te zeggen, de belofte is niet alleen bedoeld om een verplichting op zich te nemen, maar tevens om aan de belanghebbende duidelijk te maken dat deze verplichting wordt gecreëerd. Sterker nog, het expliciet kenbaar maken dat de verplichting wordt gecreëerd is een onderdeel van het in het leven roepen van de verplichting. Het zijn geen twee gebeurtenissen, het scheppen van de verplichting èn het vertellen dat dit is gebeurd, maar slechts één gebeurtenis, namelijk het scheppen van de verplichting door te communiceren dat dit gebeurt. 
Hier zien we terug wat juristen de wilsverklaring noemen. Maar we zien tevens dat deze uitdrukking enigszins misleidend is. Wat er wordt verklaard is niet zozeer de wil van de spreker dat er een verplichting voor hem ontstaat, maar veeleer dat de spreker deze verplichting (propositionele inhoud) op zich neemt (intentie). En de verklaring dient niet te worden opgevat als een bewering dat de spreker de verplichting op zich neemt, een bewering die waar of onwaar kan zijn, maar als het op zich nemen van de verplichting, een gedraging die kan lukken of mislukken. We zien dat in het algemeen terug bij rechtshandelingen: die zijn niet waar of onwaar, maar geldig (gelukt) of ongeldig (mislukt). ${ }^{38}$

Wat is dan nog de rol van de wil, van de intentie van de spreker om een verplichting op zich te nemen? Die intentie is een voorwaarde voor het slagen van de taalhandeling die er op is gericht om de verplichting te scheppen. Het is dus niet zo dat de wil centraal staat en dat de handeling niet meer is dan het bekend maken van die wil. Nee, de handeling staat centraal en de wil is in beginsel noodzakelijk om de handeling te doen slagen. Zonder wil geen belofte, of - meer in het juridische - geen rechtshandeling. Maar dat wil nog niet zeggen dat de rechtshandeling - om nu maar in het juridische te blijven - in essentie het uiten van de wil is. De rechtshandeling is in essentie het bewerkstelligen van een rechtsgevolg door het verrichten van een handeling en voor die handeling is, normaal gesproken, de wil vereist. De rechtsgevolgen zijn dan ook, wederom normaal gesproken, de beoogde rechtsgevolgen. Niet omdat de wil het rechtsgevolg in het leven roept, maar omdat de aard van de handeling het rechtsgevolg bepaalt en omdat de aard van de handeling normaal gesproken wordt bepaald door hetgeen werd beoogd, de propositionele inhoud.

In dit verband kan het verhelderend zijn om te wijzen op de opvattingen van Hart over rechtshandelingen (al gebruikte Hart die term zelf niet). Volgens Hart bevat het recht zogenaamde veranderingsregels die aangeven hoe het recht kan worden veranderd. Deze veranderingsregels geven aan hoe rechtshandelingen kunnen worden verricht en welke rechtsgevolgen daaraan zijn verbonden. ${ }^{39}$ Deze veranderingen kunnen het recht in de vorm van abstracte rechtsregels betreffen, maar ook de rechtspositie van individuele mensen, zoals die nader wordt bepaald door bijvoorbeeld overeenkomsten en testamenten. Door deze veranderingsregels te presenteren als instrumenten die het recht biedt om het recht bewust, intentioneel, te veranderen, benadrukte Hart het taalhandelingskarakter van rechtshandelingen, zonder dit met zoveel woorden te zeggen. De aandacht voor het belang van veranderingsre- 
gels weerspiegelt in de opvatting van Hart dat de rechtswerkelijkheid institutioneel is. Juist ten gevolge van dit institutionele karakter is het mogelijk om door middel van intentionele handelingen die werkelijkheid te veranderen. Essentieel daarvoor is dat er regels zijn die bepalen hoe dat moet. In de theorie van Hart zijn dat de veranderingsregels.

\section{De regels die rechtshandelingen mogelijk maken}

Volgens Searle zal bij een geslaagde constitutieve handeling (ik hanteer maar mijn eigen terminologie) de wereld met de woorden gaan corresponderen. Dat lijkt me juist, maar dat komt niet door het inherente karakter van constitutieven, wat dat ook zou mogen zijn, maar door de context van regels waarbinnen constitutieven mogelijk zijn. ${ }^{40}$ Zoals Nieuwenhuis ook benadrukt ${ }^{41}$, worden constitutieven mogelijk gemaakt door regels. Het is te vergelijken met schaken. Zonder de regels van schaken zou het spel helemaal niet mogelijk zijn. Het is dankzij de schaakregels dat de koning schaak staat als hij wordt bedreigd door een stuk van de tegenpartij en het zijn ook de schaakregels die aangeven wanneer, en mogelijk maken dat, de koning schaakmat staat. ${ }^{42}$

\subsection{Drie soorten regels}

Ook rechtshandelingen zijn, als een bepaalde vorm van constitutieven, onderworpen aan regels; regels die niet zozeer iets voorschrijven in verband met rechtshandelingen, maar regels die aangeven

1. welke soorten gebeurtenissen hebben te gelden als een bepaald soort rechtshandelingen,

2. wie bevoegd zijn om dergelijke rechtshandelingen te verrichten en

3. wat de rechtsgevolgen van de rechtshandelingen zijn.

De eerste soort regels zou men geldt-als regels kunnen noemen, de tweede soort staat bekend als bevoegdheidsverlenende regels, en de derde soort zouden we causale regels kunnen noemen, omdat ze de gevolgen van rechtshandelingen bepalen.

De geldt-als regels kan men als het ware twee kanten oplezen. In één richting worden ze gebruikt om bepaalde gebeurtenissen te interpreteren als rechtshandelingen. In de andere richting geven ze aan wat moet worden gedaan om een bepaald soort rechtshandeling te verrichten. Artikel 6:217 lid 1 BW, dat bepaalt dat overeenkomsten tot stand komen door aanbod en aanvaarding, is daarom een voorbeeld van een geldt-als regel. Maar ook regels die vormvoorschriften aangeven kunnen 
geïnterpreteerd worden als (onderdelen van) geldt-als regels. Als niet aan het vormvoorschrift is voldaan, geldt het gebeurde immers niet als een rechtshandeling (van het beoogde type).

Het Nederlandse recht kent bevoegdheidsverlenende regels in verschillende graden van abstractie. Het meest abstract is de regel van artikel 3:32 lid 1 BW, die maakt dat in beginsel iedere natuurlijke persoon bevoegd is tot het verrichten van rechtshandelingen. Specifieker is de regel van lid 2 van hetzelfde artikel, die handelingsonbekwamen onbevoegd maakt om eenzijdige ongerichte rechtshandelingen te verrichten. Nog specifieker is de regel van artikel 4:55 BW, die betrekking heeft op het verrichten van een bepaalde soort rechtshandelingen, namelijk het maken van testamenten. Het is de functie van de specifiekere bepalingen om de kring van personen die bevoegd zijn om bepaalde soorten rechtshandelingen te verrichten nader te bepalen ten opzichte van de algemene regel van artikel 3:32 lid 1 BW. Zo brengt artikel 3:32 lid 2 BW een beperking aan ten opzichte van de algemene regel en brengt artikel 4:55 BW weer een verruiming aan ten opzichte van artikel 3:32 lid 2.

Causale regels spelen niet alleen een rol bij rechtshandelingen, maar eigenlijk bij alle rechtsfeiten, gebeurtenissen waaraan het recht rechtsgevolgen verbindt. We zullen zien dat een belangrijke manier om causale regels onder te verdelen, te maken heeft met de kwestie of ze rechtsgevolgen afhankelijk maken van de vraag of deze rechtsgevolgen werden beoogd.

\subsection{Het instituut 'rechtshandeling'}

In theorie zouden de drie soorten regels die rechtshandelingen mogelijk maken elke inhoud kunnen hebben. Zo is het, geheel hypothetisch, denkbaar dat er een regel is die niezen maakt tot een 'rechtshandeling'.43 Er zou dan vervolgens een corresponderende causale regel kunnen zijn, die inhoudt dat wie niest $€ 100$ moet betalen aan iedereen die deze gebeurtenis heeft waargenomen.

De voor de hand liggende tegenwerping tegen de mogelijkheid van dergelijke regels over de rechtshandeling 'niezen' is dat niezen in deze constructie in het geheel geen rechtshandeling is. Het lijkt meer op een regeling van een nieuw type verbintenis uit de wet dan op een regeling van een nieuw type rechtshandeling. Dat komt, omdat het bestaan van het instituut rechtshandeling wordt mogelijk gemaakt door een bepaalde soort regels die behoren tot de bovengenoemde categorieën 1 en 3 . We spreken slechts van rechtshandelingen als de geldt-als regels op enigerlei wijze de eis stellen dat de handelende persoon beoogde om door middel 
van zijn handeling rechtsgevolgen in het leven te roepen en als de betreffende causale regels het intreden en de aard van de rechtsgevolgen afhankelijk maken van deze intentie van de rechtshandelaar. 44

Hier zou een misverstand kunnen rijzen, namelijk dat hier de opvatting wordt verdedigd dat slechts intentionele handelingen als rechtshandelingen hebben te gelden. Het zou dan gaan om een normatieve opvatting, een opvatting over hoe het recht zou moeten luiden en meer specifiek over de vraag onder welke omstandigheden een rechtshandeling dient te worden aangenomen. Dit is niet wat ik bedoel. Wat ik duidelijk wil maken, is dat in veel moderne rechtssystemen regels bestaan die een speciale betekenis toekennen aan handelingen waarmee wordt beoogd om rechtsgevolgen in het leven te roepen. Deze regels verbinden aan dergelijke handelingen het rechtsgevolg dat de beoogde rechtsgevolgen inderdaad intreden. De rechtssystemen die dergelijke regels hebben, hebben daarmee een instituut dat in Duitsland Rechtsgeschäft wordt genoemd, in Frankrijk acte juridique en in Nederland rechtshandeling. Dat instituut bestaat in Engeland ook, maar het Engelse recht wijdt er geen afzonderlijk leerstuk aan en er is ook geen speciale naam voor. Het instituut rechtshandeling bestaat, voor zover het binnen een bepaald rechtssysteem bestaat, in de vorm van een aantal geldt-als en causale regels die de hierboven beschreven inhoud hebben. Dankzij het bestaan van deze regels hebben bepaalde handelingen een speciale juridische betekenis. Dat zijn rechtshandelingen, of het rechtssysteem ze zo noemt of niet.

Als een rechtssysteem het instituut rechtshandeling kent, is het per definitie zo dat rechtshandelingen normaal gesproken de beoogde rechtsgevolgen hebben. Zo kan bijvoorbeeld de vraag of een overeenkomst inderdaad leidt tot de verplichtingen die partijen hebben afgesproken enkel onder uitzonderlijke omstandigheden zinvol zijn. Het vloeit uit de aard van rechtshandelingen voort dat de beoogde rechtsgevolgen van overigens geldige rechtshandelingen normaal gesproken intreden. Dit geldt ook voor overeenkomsten, voor zover men die als rechtshandelingen beschouwt. 45 Het is de strekking van dergelijke overeenkomsten dat partijen daarmee beogen hun juridische relatie voor de toekomst aan te passen, voornamelijk door verplichtingen jegens elkaar te scheppen. Als een rechtssysteem werkt met overeenkomsten als rechtshandelingen, wil dit zeggen dat de door partijen beoogde rechtsgevolgen normaal gesproken ook intreden. Dit sluit niet uit dat er onder bijzondere omstandigheden uitzonderingen kunnen zijn, maar dat moeten dan uitzonderingen zijn. ${ }^{46}$ 
Het kan zinvol zijn om aandacht te besteden aan de vraag of en onder welke omstandigheden partijen door overeenkomsten worden gebonden. Deze vragen zullen in het algemeen - namelijk als zich geen uitzonderlijke omstandigheden voordoen - moeten worden geïnterpreteerd als de vraag of overeenkomsten als rechtshandelingen een zinvol juridisch instituut zijn. Is het nuttig, of goed, om binnen een rechtssysteem een samenstel van regels te hebben die het voor partijen mogelijk maken om binnen bepaalde grenzen hun toekomstige rechtsverhoudingen zelf aan te passen? Als men deze vraag bevestigend beantwoordt en het instituut rechtshandeling in het recht adopteert, dan is daarmee het verbindende karakter van rechtshandelingen vastgelegd en is het in beginsel boven discussie of de door partijen met een rechtshandeling beoogde rechtsgevolgen zullen intreden. ${ }^{47}$

Het bovenstaande zou aanleiding kunnen geven tot de beschuldiging van Begriffsjurisprudenz. ${ }^{48}$ Eerst wordt aangegeven wat het wezen van de rechtshandeling is en vervolgens wordt gestipuleerd dat uit deze aard voortvloeit dat rechtshandelingen de beoogde rechtsgevolgen hebben. Op deze manier wordt een normatieve conclusie over de rechtsgevolgen van bepaalde vormen van gedrag binnengesmokkeld via een schijnbaar neutrale analyse van wat rechtshandelingen in wezen zouden zijn.

Hoe begrijpelijk deze lezing ook moge zijn, hij is misleidend. Het misleidende zit hem erin dat lijkt te worden aangenomen dat bepaalde gebeurtenissen die traditioneel als rechtshandelingen worden aangemerkt, inderdaad rechtshandelingen zijn en de bij rechtshandelingen behorende rechtsgevolgen hebben. Meestal zal dat ook het geval zijn, maar het is mogelijk dat die rechtsgevolgen soms niet intreden. Dat kan dan twee oorzaken hebben. Enerzijds is het mogelijk dat het weliswaar om een rechtshandeling gaat, maar dat de beoogde rechtsgevolgen bij wijze van uitzondering niet intreden. Anderzijds kan het zijn dat een bepaalde gebeurtenis niet als rechtshandeling in de hierboven gepreciseerde zin heeft te gelden, al wordt hij traditioneel als zodanig aangemerkt. Zo heeft een zwartrijder in de trein mijns inziens geen contract gesloten met de spoorwegen. Er valt ongetwijfeld veel voor te zeggen om de zwartrijder geld te laten betalen, maar die verplichting is geen verbintenis uit overeenkomst en berust niet op een rechtshandeling.

Meer in het algemeen is de strekking van het bovenstaande betoog over rechtshandelingen niet zozeer dat onder bepaalde omstandigheden bepaalde rechtsgevolgen moeten worden aangenomen, maar veeleer dat onder bepaalde omstandigheden de rechtshandelingsconstructie voor het aannemen van rechtsgevolgen gebruikt zou moeten 
worden. Het gaat dus niet zozeer om de rechtsgevolgen die al dan niet moeten intreden, als wel om de weg die gekozen wordt om die rechtsgevolgen al dan niet te laten intreden.

\section{Rechtshandelingen binnen en in het recht}

De meeste, zo niet alle, rechtssystemen maken het mogelijk om de inhoud van de rechtswerkelijkheid te veranderen door middel van op deze verandering gerichte handelingen. Ze hebben regels die aangeven wanneer er sprake is van zo'n handeling, wie bevoegd zijn om dergelijke handelingen te verrichten en die bepalen dat de met die handelingen beoogde rechtsgevolgen inderdaad intreden. Deze systemen kennen het instituut rechtshandeling. Maar zoals we al hebben gezien, wil het feit dat binnen een rechtssysteem met rechtshandelingen wordt gewerkt nog niet zeggen dat het begrip 'rechtshandeling' in het betreffende rechtssysteem voorkomt. Het Engelse recht is daar een voorbeeld van: het werkt wel met rechtshandelingen, maar niet met het begrip 'rechtshandeling'.

Rechtssystemen die het begrip 'rechtshandeling' wel kennen, zoals het Duitse en het Nederlandse, vertonen vaak discrepanties tussen wat een rechtshandeling abstract beschouwd is en de wijze waarop de rechtshandeling in het betreffende recht is geregeld. Een belangrijke reden daarvoor is dat rechtshandelingen fungeren als een bron van verbintenissen en dat de antwoorden op de vragen of er sprake is van een rechtshandeling en welke verbintenissen uit deze rechtshandelingen voortvloeien, in belangrijke mate bepaald worden door de kwestie welke verbintenissen wenselijk worden geacht. Op deze wijze worden twee kwesties als één behandeld, namelijk de aard en de rechtsgevolgen van rechtshandelingen en welke verbintenissen moeten worden aangenomen in situaties waarin rechtshandelingen of daarop gelijkende gebeurtenissen voorkomen. $49 \mathrm{lk}$ zal hieronder twee voorbeelden bespreken van wat in mijn ogen een verwarring van deze twee kwesties is.

\subsection{Normatieve toerekening}

Het is mogelijk het verbindende karakter van overeenkomsten bijna volledig los te maken van inhoudelijke en formele gronden en enkel nog aan te geven dat het recht bepaalt wat, onder welke omstandigheden, als rechtshandeling heeft te gelden en wat de daaruit voortvloeiende rechtsgevolgen zijn. Deze aanpak wordt gekozen door Van Dunné in zijn theorie over de normatieve uitleg van rechtshandelingen. Van Dunné zelf noemt deze theorie de toerekeningsleer en hij omschrijft deze als volgt: 
Een rechtshandeling is een handeling van een persoon, bestaande in een doen of niet-doen, waardoor krachtens de normen van het geldend recht - gezien de aard van de handeling, de omstandigheden waaronder, en de wijze waarop zij tot stand kwam - rechtsgevolgen ontstaan die de handelende worden toegerekend.

Onder de uitleg van een rechtshandeling wordt verstaan het vaststellen van de rechtsgevolgen die de handelende persoon worden toegerekend. ${ }^{\circ}$

Het valt op dat de omschrijving door Van Dunné van een rechtshandeling zo ruim is, dat vele onrechtmatige gedragingen, ook onrechtmatige gedragingen waarmee in het geheel geen rechtsgevolg werd beoogd, er onder zouden vallen. ${ }^{51}$ Een rechtshandeling is volgens deze theorie niets anders dan een handeling die rechtsgevolgen meebrengt die de handelende persoon regarderen. In deze theorie wordt de rechtshandeling gezien als een gebeurtenis met rechtsgevolgen, zonder dat de wil van de handelende persoon daar, althans wat de definitie betreft, een wezenlijke rol in speelt.

De kracht van deze theorie van Van Dunné is dat hij er oog voor heeft dat het recht aan gebeurtenissen de rechtsgevolgen kan verbinden die het recht wil, ook in afwijking van de wil van de handelende persoon. De zwakte is dat dit resultaat wordt bereikt door een rechtshandeling op te vatten als een rechtsfeit dat toevallig ook nog een handeling is. De categorie 'rechtshandeling' wordt hiermee overbodig naast die van het rechtsfeit.

Nu zou men kunnen verdedigen dat dit geen zwakte is van de theorie, maar juist winst, omdat het onderscheid tussen 'gewone' rechtsfeiten en rechtshandelingen toch zonder praktisch belang is. Maar dat zou over het hoofd zien dat de rechtshandeling als instrument om de juridische positie van één of meer mensen te veranderen een bijzondere positie inneemt temidden van de andere soorten rechtsfeiten. Deze bijzondere positie komt onder meer tot uitdrukking in de betekenis die de intentie (wil) van de handelende persoon heeft bij het vaststellen van de rechtsgevolgen van rechtshandelingen. Een theorie die een dergelijk onderscheid 'wegreduceert' is niet aantrekkelijk, omdat een goede theorie kan bewerkstelligen dat door middel van het maken van adequate categorieën de juridische werkelijkheid beter hanteerbaar kan worden gemaakt. Daarom lijkt me dat de opvatting van Van Dunné verworpen moet worden als theorie over de aard van rechtshandelingen. Daarmee is niets gezegd over de kwaliteit van die theorie als opvatting over de bronnen van verbintenissen. 


\subsection{Vertrouwen als vervanger van de wil}

In veel rechtssystemen wordt aangenomen dat een overeenkomst tot stand kan komen op grond van opgewekt vertrouwen, ook al ontbrak de relevante wil. Dit kan worden geconstrueerd als een afzonderlijke grondslag voor het bestaan van een overeenkomst ${ }^{52}$, maar ook door het 'oprekken' van wat geldt als wilsverklaring. ${ }^{53}$ Dat op grond van vertrouwen rechtsgevolgen worden geschapen die vergelijkbaar zijn met die van een gewone geldige wilsverklaring is te rechtvaardigen, bijvoorbeeld op grond van de belangen van het handelsverkeer. Dat deze rechtsgevolgen worden geschapen doordat er, ondanks het ontbreken van de wil, toch een geldige rechtshandeling wordt aangenomen, past niet in het beeld van de rechtshandeling als afzonderlijk instituut van het recht. Het zou zuiverder zijn om aan te nemen dat deze rechtsgevolgen worden verbonden (toegerekend) aan het vertrouwenwekkende gedrag sec, zonder dat te doen via de tussenliggende constructie dat, hoewel de relevante wil ontbrak, toch een geldige overeenkomst is ontstaan.

Een dergelijke constructie zou ook kunnen worden toegepast ten aanzien van algemene voorwaarden. Het is denkbaar dat het op bepaalde gronden - zoals bijvoorbeeld de belangen van het handelsverkeer - wenselijk is dat gebondenheid aan algemene voorwaarden ontstaat, ook als een van de contractspartijen de inhoud daarvan niet kende. Dan is het zuiverder deze gebondenheid niet te baseren op een contract, maar rechtstreeks op de gronden die gebondenheid wenselijk maken. Een dergelijke constructie maakt het bovendien eenvoudiger om, indien dat wenselijk is, de gebondenheid aan standaardvoorwaarden anders te regelen dan gebondenheid aan contractuele bepalingen waarover wel echte wilsovereenstemming heeft bestaan. 54

Dat bij gerechtvaardigd vertrouwen toch in het algemeen een overeenkomst wordt aangenomen en niet enkel de uit een overeenkomst voortvloeiende verbintenissen, kan op twee manieren worden verklaard. De ene verklaring luidt dat de wil om rechtsgevolgen in het leven te roepen noodzakelijkerwijs altijd uit feitelijke omstandigheden moet worden opgemaakt, dat wil zeggen uit feiten die het vertrouwen rechtvaardigen dat een dergelijke wil aanwezig is. Het is dan verleidelijk om het vereiste van een wil te vervangen door het vereiste dat er gerechtvaardigd vertrouwen was, zeker als dat er toe leidt dat bij gerechtvaardigd vertrouwen zonder wil de wenselijk geachte rechtsgevolgen intreden. De andere verklaring heeft te maken met juridisch conservatisme. Het recht kent een aantal gronden waarop het bestaan van een verbintenis pleegt te worden aangenomen. Het is dan verleidelijk om in gevallen waarin het 
aantrekkelijk is om een verbintenis aan te nemen, maar waarin een voor de hand liggende grondslag ontbreekt, de vereiste grondslag te construeren via het oprekken van een bestaande grondslag. Dan lijkt het of het recht niet echt wordt veranderd, terwijl het toch kan worden aangepast aan wat wenselijk wordt geoordeeld.

Beide gronden zijn niet overtuigend. De eerste niet omdat die geen recht doet aan situaties waarin uiteindelijk op grond van feitelijke omstandigheden blijkt dat toch geen wil aanwezig was. Het kan dan redelijk zijn om de wederpartij te beschermen, maar daaruit volgt niet dat het redelijk is om een overeenkomst aan te nemen. Het aannemen van een overeenkomst is maar één manier om de gewenste bescherming tot stand te brengen en wel een gekunstelde. De tweede grond is niet overtuigend omdat het aanhaken bij een bestaand, maar strikt genomen niet toepasselijk leerstuk, teneinde wenselijk geachte rechtsgevolgen te bewerkstelligen, enkel maar de (oppervlakkige) schijn oproept dat het recht niet werd gewijzigd. Ook leidt het niet tot meer rechtszekerheid dan het aanvaarden van de wenselijk geachte rechtsgevolgen zuiver op grond van het opgewekte vertrouwen.

\subsection{Verbintenissen naar aanleiding van een overeenkomst}

Mijns inziens is het onwenselijk dat het instituut rechtshandeling wordt gebruikt om het bestaan van verbintenissen te rechtvaardigen waar die verbintenissen eigenlijk helemaal niet waren beoogd door de personen aan wie de vermeende rechtshandeling wordt toegeschreven. Dat vertroebelt enkel maar het inzicht in wat rechtshandelingen zijn en leidt tot vage theorieën over de aard van rechtshandelingen zoals die van Van Dunné. Maar als rechtshandelingen enkel worden aangenomen waar mensen beoogden door middel van hun handelingen bepaalde rechtsgevolgen in het leven te roepen, moet het recht alternatieve oplossingen bieden voor die gevallen waarin rechtsgevolgen wenselijk zijn en die nu 'opgelost' worden door het instituut rechtshandeling op te rekken tot buitenissige proporties. Een deel van die oplossingen kan worden geboden door behalve verbintenissen uit overeenkomst (die dus waren beoogd door partijen) ook verbintenissen naar aanleiding van een overeenkomst aan te nemen.

De causale regels die rechtsgevolgen verbinden aan gebeurtenissen, kunnen in theorie elke mogelijke inhoud hebben. Maar als een rechtssysteem het instituut 'rechtshandeling' kent, zullen de causale regels aan geldige rechtshandelingen gewoonlijk het gevolg verbinden dat de beoogde rechtsgevolgen intreden. Dat zegt niets over niet-beoogde 
rechtsgevolgen. Het recht is helemaal vrij in de kwestie of er niet-beoogde rechtsgevolgen aan rechtshandelingen worden verbonden, en zo ja welke dat dan zijn.

Eén bepaalde gebeurtenis kan door het recht zowel als rechtshandeling worden geïnterpreteerd (en dan krijgt die gebeurtenis de beoogde rechtsgevolgen, of een deel daarvan), als wel als een 'gewone' gebeurtenis, waaraan door het recht de gevolgen worden toegekend die het recht maar wil. In dit verband kan het recht belang hechten aan het feit dat de betreffende gebeurtenis tevens een rechtshandeling is van een bepaald type. Zo hecht artikel 6:248 lid 1 BW waarde aan het feit dat een bepaalde gebeurtenis het sluiten van een (willekeurige) overeenkomst is en hecht artikel 1645 van de Franse Code Civil belang aan het feit dat een bepaalde gebeurtenis als het sluiten van een koopovereenkomst geldt.

Strikt genomen zijn de verplichtingen waar deze bepalingen het over hebben dan ook geen verbintenissen uit overeenkomst, want partijen zijn niet overeengekomen dat ook deze verbintenissen zouden ontstaan. ${ }^{5}$ Maar voor het ontstaan van deze verbintenissen is het wel nodig dat een (bepaald soort) overeenkomst is gesloten. Men zou dergelijke verbintenissen dan ook goed verbintenissen naar aanleiding van een overeenkomst kunnen noemen. Dergelijke verbintenissen naar aanleiding van een overeenkomst zijn op het eerste gezicht moeilijk te plaatsen als rechtshandelingen primair worden gezien als instrumenten om de wil van de handelende persoon rechtens te realiseren. Maar ze zijn niets nieuws, namelijk 'gewone' rechtsgevolgen, als men zich realiseert dat een rechtshandeling behalve een rechtshandeling ook altijd nog een gebeurtenis is waaraan het recht gevolgen verbindt..$^{56}$

Heeft het zin om binnen de rechtsgevolgen van een overeenkomst te onderscheiden tussen de met de overeenkomst beoogde rechtsgevolgen, die intreden omdat ze werden beoogd, en andere rechtsgevolgen? Dat heeft geen zin als men principieel niet wil onderscheiden tussen beoogde en niet-beoogde rechtsgevolgen. Maar als men zich omstandigheden kan voorstellen waarin het verschil maakt of een bepaald rechtsgevolg door beide partijen bij een overeenkomst was beoogd, dan is het onderscheid tussen verbintenissen uit en verbintenissen naar aanleiding van een overeenkomst zinvol. In de moderne rechtspraktijk is het gebruikelijk om onderscheid te maken tussen contractsbepalingen waarover expliciete overeenstemming bestaat en andere bepalingen, meestal uit algemene voorwaarden. ${ }^{57}$ Dit onderscheid is beter te plaatsen in het licht van het andere onderscheid tussen verbintenissen uit en naar aanleiding van een overeenkomst. 


\subsection{Weg met de bronnen van verbintenissen!}

Het aannemen van verbintenissen naar aanleiding van een overeenkomst is een stap op de goede weg, maar die weg kan maar beter ten volle worden gegaan. Welke weg is dat en waar leidt hij naar toe? Ik moet hierover in een analyse van de aard van rechtshandelingen noodzakelijkerwijs korter van stof zijn dan wetenschappelijk verantwoord is.

Zoals reeds eerder opgemerkt is een belangrijke reden om rechtshandelingen aan te nemen waar ze niet zijn dat er behoefte bestaat om het bestaan van verbintenissen te rechtvaardigen. Onder invloed van oude doctrines uit het Romeinse recht wordt in een aantal Europese rechtssystemen gewerkt met de leer dat verbintenissen herleid moeten kunnen worden tot een 'bron'. Zonder bron geen verbintenis. Aangezien het regelmatig voorkomt dat het bestaan van een verbintenis wenselijk zou zijn, maar het moeilijk is om voor die verbintenis een bron aan te wijzen, worden zowel het leerstuk van de bronnen als de aard van die bronnen opgerekt. Als we ons tot het Nederlandse recht beperken, zien we dat verbintenissen niet meer rechtstreeks op een rechtshandeling of de wet hoeven te stoelen, maar ook kunnen voortvloeien uit het systeem van de wet. ${ }^{8}$ Bovendien worden bestaande bronnen opgerekt om maar de gewenste verbintenissen te kunnen rechtvaardigen. De leer van de dubbele grondslag van rechtshandelingen die in de artikelen 3:33 en 35 BW is neergelegd is daar het meest sprekende voorbeeld van, maar ook het oprekken van de onrechtmatige daad teneinde verbintenissen te kunnen aannemen waar eigenlijk rechtmatig werd gehandeld 59 is daar een voorbeeld van.

In dit licht ware het beter als de eis dat een verbintenis gebaseerd dient te zijn op een erkende 'bron' zou komen te vervallen. Dit wil niet zeggen dat in het wilde weg verbintenissen zouden moeten worden aangenomen, waar dit maar redelijk of billijk lijkt. Er valt veel voor te zeggen om te komen tot systematische theorievorming over de omstandigheden waaronder het bestaan van rechtsplichten wordt aangenomen en wanneer er tegenover die rechtsplichten rechtsvorderingen staan en wanneer die rechtsvorderingen uitgroeien tot vorderingsrechten. De rechtspraktijk lijkt echter uit te wijzen dat de huidige doctrine over bronnen van verbintenissen daartoe niet het meest geschikte instrument is. Mede om het instituut van de rechtshandeling niet te belasten met de taak aan te geven wanneer het bestaan van verbintenissen dient te worden aangenomen, zou de doctrine over de bronnen van verbintenissen moeten worden afgeschaft in het geldende recht en zou hij dienen te worden overgelaten aan de rechtshistorici. 


\section{Conclusie}

Het is mogelijk om het begrip rechtshandeling in het recht van een bepaald land te gebruiken als instrument om bepaalde onderwerpen te regelen. Aan het bestaan van een rechtshandeling worden dan bepaalde rechtsgevolgen verbonden en via de voorwaarden voor het bestaan van een rechtshandeling - bijvoorbeeld door nadruk te leggen op wil, of juist vertrouwen - wordt nader inhoud gegeven aan de omstandigheden waaronder deze rechtsgevolgen intreden. De aard van een rechtshandeling is dan deel van de inhoud van het positieve recht en verschillende rechtssystemen hebben dan (licht) verschillende soorten rechtshandelingen.

Dit is één manier om tegen rechtshandelingen aan te kijken, maar volgens mij niet de meest verhelderende. Door het rechtshandelingsbegrip te beschouwen als deel van het positieve recht, gaat het zicht verloren op wat rechtshandelingen in verschillende systemen gemeen hebben en op wat rechtshandelingen doet verschillen van andere rechtsfeiten. Met name voor rechtsvergelijkende doeleinden is het van belang om te abstraheren van de wijzen waarop rechtshandelingen, al dan niet expliciet, binnen de verschillende systemen worden geregeld. Dat maakt het mogelijk om meer inzicht te krijgen in wat rechtshandelingen precies zijn - dat is iets anders dan hoe ze geregeld zijn - en om met een wat afstandelijker blik te kijken naar de wijzen waarop in verschillende rechtssystemen met rechtshandelingen wordt omgegaan.

In deze bijdrage heb ik geprobeerd om de aanzet voor zo'n abstracte theorie over de aard van rechtshandelingen te geven. Daartoe heb ik met name aandacht besteed aan de vooronderstellingen van een instituut waarin de werkelijkheid van het recht afhankelijk wordt gemaakt van de intentionele handelingen van bepaalde personen (of instellingen). Deze vooronderstellingen komen er op neer dat de werkelijkheid van het recht een speciaal deel van de sociale werkelijkheid is en wel een geïnstitutionaliseerd deel. In zo'n geïnstitutionaliseerde werkelijkheid bepalen regels wat de feiten zijn, zoals welke rechtsregels gelden en wie welke rechten en plichten heeft.

Bij een geïnstitutionaliseerde werkelijkheid is het in het algemeen handig als het mogelijk is om de feiten opzettelijk te veranderen. Als de feiten afhankelijk zijn van regels, wil dit zeggen dat het handig is om regels te hebben die aan handelingen die worden verricht met de bedoeling om de rechtswerkelijkheid aan te passen, het (rechts)gevolg verbinden dat de beoogde aanpassingen inderdaad plaats vinden. Rechtssystemen die dergelijke regels hebben, kennen het instituut 
rechtshandeling. Rechtshandelingen verschillen van andere rechtsfeiten doordat ze instrumenten zijn om het recht opzettelijk te veranderen. Dat is een belangrijk verschil dat mijns inziens verdient om te worden gehandhaafd en daarom is het zinvol om rechtsfeiten onder te verdelen in twee categorieën:

1. de rechtshandelingen waarmee veranderingen in de rechtswerkelijkheid bewust worden bewerkstelligd;

2. de overige rechtsfeiten, die weliswaar ook leiden tot veranderingen in de rechtswerkelijkheid, maar waarbij de veranderingen onafhankelijk zijn van de wil om specifiek die rechtsgevolgen te bewerkstelligen.

Wil een rechtssysteem het instituut rechtshandeling hebben, dan moeten er tenminste twee soorten regels zijn, namelijk regels die aangeven welke van de handelingen die de strekking hebben veranderingen aan te brengen in de rechtswerkelijkheid als rechtshandelingen gelden en regels die bepalen dat de beoogde veranderingen in grote lijnen inderdaad intreden. ${ }^{60}$ In het algemeen zal er nog een derde soort regels zijn, die aangeven wie bevoegd is om rechtshandelingen (van een bepaalde soort) te verrichten.

Het is mogelijk om binnen een rechtssysteem een expliciete regeling op te nemen over rechtshandelingen. Zo'n regeling is echter niet nodig voor het bestaan van het instituut rechtshandeling binnen een rechtssysteem. Als rechtshandelingen expliciet worden geregeld, zou het wenselijk zijn die regeling nauw te laten aansluiten bij de essentie van rechtshandelingen zoals hierboven uiteengezet. Dan is de intentie om door middel van een handeling rechtsgevolgen in het leven te roepen essentieel voor het bestaan van een rechtshandeling en zijn de rechtsgevolgen in beginsel de beoogde.

In praktijk wordt de regeling van rechtshandelingen veelal gebruikt als instrument om inhoudelijk wenselijk recht te bewerkstelligen. Zo wordt het bestaan van een bepaald soort rechtshandeling ook wel aangenomen als de intentie om de betreffende rechtsgevolgen in het leven te roepen ontbrak en worden er aan het bestaan van een rechtshandeling ook rechtsgevolgen gekoppeld die niet waren beoogd. Het onderscheid tussen rechtshandelingen en andere rechtsfeiten komt daarbij onder druk te staan. Mijns inziens zou het leerstuk van de rechtshandeling niet moeten worden belast met elementen die daar eigenlijk weinig mee te maken hebben, zoals de kwestie welke verbintenissen er (dienen te) bestaan. Het schrappen van de leer dat verbintenissen op een zogenaamde bron dienen te berusten zou hierbij dienstig zijn. ${ }^{61}$ 
Noten

$1 \AA$. Frändberg, 'An Essay on the Systematics of Legal Concepts', in dezelfde, Rättsordningens idé, Uppsala: lustus Forläg, 2005, 63-96.

2 http://www.pitt.edu/ dash/alibaba.html (laatst gecontroleerd op 10 mei 2007)

3 Zo heb ik in mijn artikel 'Rechtsplichten, verbintenissen en schadevergoeding bij rechtmatige daad', NTBR 23 (2006), 264-271, geprobeerd te laten zien hoe het niet scherp onderscheiden van rechtsplichten en verbintenissen heeft geleid tot minder heldere discussies over schadevergoeding bij rechtmatige (overheids)daad.

4 Een uitzondering in Nederland is J.H. Nieuwenhuis, Drie beginselen van contractenrecht, Deventer: Kluwer 1979, die een aantal bladzijden wijdt aan de vraag wat een rechtshandeling is en die een opvatting uitdraagt welke verwant is aan een deel van wat ik hier betoog.

5 Over de noodzakelijkheid van zo een abstract begrippenkader, zie K. Zweigert en H. Kötz, Introduction to Comparative Law, ze druk vertaald door T. Weir, Oxford: Clarendon Press 1998, 44. Uitvoeriger over deze 'comparatieve begrippen' is C.J.P. van Laer, Het nut van comparatieve begrippen, Antwerpen: Intersentia 1997.

6 Bij benadering hetzelfde onderscheid wordt gemaakt door Frändberg in zijn aan het begin van dit stuk geciteerde artikel An Essay on the Systematics of Legal Concepts.

7 Meer hierover in Bob Brouwer en Jaap Hage, 'Basic concepts of European Private Law', European Review of Private Law 1-2007, 3-26, met name de passages over 'placeholder concepts'.

8 O. Lando en H. Beale (red.), Principles of European Contract Law, Pts I and II, Den Haag: Kluwer 1995.

9. Zoals later zal blijken is het eerder zo dat wetgeving een speciaal soort rechtshandeling is, dan dat rechtshandelingen op wetgeving lijken. Anders dan Flume aanneemt, zijn rechtshandelingen niet beperkt tot het privaatrecht. (W. Flume, Allgemeiner Teil des Bürgerlichen Rechts. Das Rechtsgeschäft. ze druk, Berlijn: Springer 1979, 34.) Weliswaar is het begrip rechtshandeling ontwikkeld in de privaatrechtswetenschap, maar dat brengt niet mee dat het eenmaal ontwikkelde begrip enkel van toepassing kan zijn in het rechtsgebied waarbinnen het ontwikkeld is.

10 E.M. Meijers, De algemene begrippen van het burgerlijk recht, Leiden: Universitaire Pers 1947, 288. Cursivering weggelaten en toegevoegd.

11 K. Larenz en M. Wolf, Allgemeiner Teil des bürgerlichen Rechts, ge Auflage, München: Beck 2004, 439. Nadruk weggelaten.

12 Jacques Ghestin, Traité de droit civil. La formation du contrat, ze druk, Parijs: L.G.D.J. 1993, 27.

13 Von Savigny, System des römischen Rechts, III, 258. Geciteerd naar Flume, Allgemeiner Teil des Bürgerlichen Rechts. Das Rechtsgeschäft, 49. Cursivering toegevoegd.

14 J.M. van Dunné, Normatieve uitleg van rechtshandelingen. Een onderzoek naar de grondslagen van het geldende verbintenissenrecht, Deventer: Kluwer 1971, 8 e.v. en Verbintenissenrecht deel 1, 5e druk, Deventer: Kluwer 2004, 133. 
15 Vgl. J. Eggens, 'Een man een man, een woord een woord', in H.C.F. Schoordijk en J.M. Smits, Eggens bundel, Overveen: Belvédère 1998, 352.

16 Vgl. Van Dunné, Verbintenissenrecht deel 1, 135 e.v.

17 Het gaat hier om een noodzakelijke, niet perse om een voldoende voorwaarde. Ook in de wilstheorie is het mogelijk dat niet elke handeling met een beoogd rechtsgevolg dit rechtsgevolg ook meebrengt.

18 Het is bijvoorbeeld denkbaar dat de handelende persoon beoogde zowel zichzelf als een ander te binden, maar dat hij slechts competent was om zichzelf te binden, zodat de binding van de ander niet tot de rechtsgevolgen behoort.

19 Dit thema wordt uitgewerkt in J.R. Searle, The Construction of Social Reality, New York: The Free Press 1995, 32 e.v. Searle bouwt daarin voort op gedachtegoed van Berger en Luckman over institutionalisering. Vgl. P. Berger en Th. Luckman, The social construction of reality, Harmondsworth: The Penguin Press 1967,65 e.v.

20 De restrictie tot relevante personen heeft er mee te maken dat er bij de constructie van de sociale werkelijkheid soms sprake is van een rolverdeling. Niet iedereen heeft evenveel invloed op wat als recht heeft te gelden. Rechters verkeren wat dat betreft bijvoorbeeld in een bevoorrechte positie. Dit thema komt uitvoeriger aan de orde in H.L.A. Hart, The Concept of Law, 2nd. ed., Oxford: University Press 1994, 111 e.v.

Zie voor een vergelijkbaar thema ten aanzien van linguïstische rolverdeling H. Putnam, 'Meaning and Reference', in S.P. Schwartz (red.), Naming, Necessity and Natural Kinds, Ithaca: Cornell University Press 1977, 119-132.

21 Deze opvatting, die door de meeste mensen zal worden gedeeld, staat onder filosofen bekend als realisme. (Vgl. P. Railton en G. Rosen, 'Realism' in J. Kim en E. Sosa, A Companion to Metaphysics, Oxford: Blackwell 1995, 436-437.) Zoals uit het bestaan van een speciale naam voor de opvatting al blijkt, wordt dit realisme niet door iedereen onderschreven.

22 Of dit nu precies de juiste definitie is van institutionalisering valt te betwisten. Zo schrijven Berger en Luckman 'Institutionalization occurs whenever there is a reciprocal typification of habitualized actions by types of actors'. (The social construction of reality, 72.) Dat is toch iets anders dan dat de feiten op regels gebaseerd zijn.

Ik gebruik de term 'institutionalisering' hier toch maar, omdat hij in de rechtstheorie ingeburgerd is. Vgl. bijvoorbeeld N. MacCormick, ' Law as Institutional Fact', in Neil MacCormick en Ota Weinberger, An Institutional Theory of Law. New Approaches to Legal Positivism, Dordrecht: Reidel 1986, 4976.

23 Dit verschijnsel staat bekend als de 'Stufenbau' van het rechtssysteem (vgl. H. Kelsen, Reine Rechtslehre, ze druk, Wenen: Franz Deuticke 1960, 228 e.v.), of - meer prozaïsch - als getrapte regelgeving. Zoals Hart al heeft uitgelegd aan de hand van zijn theorie over de Ultimate Rule of Recognition, moet de recursie van institutionele feiten gebaseerd op ander institutionele feiten eindigen in 'gewone' feiten in de sociale werkelijkheid. De Ultimate Rule of Recognition dient te bestaan als sociale regel, niet als rechtsregel. (The Concept of LaW, 101 e.v. Vgl. ook D.W.P. Ruiter, Institutional Legal Facts, Dordrecht: Kluwer 1993, 11 e.v. 
24 Meer over het bestaan van plichten in de werkelijkheid in mijn proefschrift Feiten en betekenis (Leiden 1987) en in mijn artikel 'What is a norm?' in Jaap Hage, Studies in Legal Logic, Dordrecht: Springer 1995, 159-202.

25 Overigens is er wel een probleem als institutionele feiten, feiten die bestaan dankzij een regel, alom niet erkend worden. Als bijvoorbeeld een wettelijke bepaling die geldig tot stand is gekomen alom als non-recht wordt ervaren, is het voor discussie vatbaar of deze bepaling wel recht is. Zie voor deze discussie G. Radbruch, 'Gesetzliches Unrecht und übergesetzliches Recht', in diens Rechtsphilosophie, Koehler, Stuttgart 1973, 339-350 en de reactie daarop van Hart, The Concept of Law, 203 e.v. Een beschouwing die theoretisch dieper graaft, is te vinden in Ruiter, Institutional Legal Facts, 97 e.v.

26 Dit is een centraal thema in Hart's The Concept of Law, maar ook al in A. Ross, On Law and Justice, Berkeley: University of California Press 1959, 11 e.v.

27 J.L. Austin, How to do things with words, 2nd ed. edited by J.O. Urmson and M. Sbisa, Oxford: University Press 1975.

28 J.R. Searle, Speech acts. An essay in the philosophy of language. Cambridge: University Press 1969.

29 Vgl. Wiggins' stelling dat identiteit in het algemeen soortafhankelijk is ( $a$ is niet zomaar hetzelfde als b, maar bijvoorbeeld dezelfde handeling, of hetzelfde boek), in D. Wiggins, Sameness and Substance, Oxford: Basil Blackwell 1980,15 e.v.

$30 \mathrm{Er}$ zijn ook geestestoestanden met een propositionele inhoud, zoals geloven dat het regent, vrezen dat het regent, of boos zijn dat het regent. Men noemt deze geestestoestanden 'propositionele houdingen'. (Meer hierover in S. Haack, Philosophy of Logics, Cambridge: University Press 1978, 124 e.v.) Taalhandelingen liggen op het grensvlak van deze propositionele houdingen en handelingen die geen propositionele inhoud hebben.

31 Searle schrijft over de 'directions of fit'. Zie J.R. Searle, 'A Taxonomy of Illocutionary Acts', in dezelfde, Expression and Meaning. Studies in the Theory of Speech Acts, Cambridge: University Press 1979, 1-29.

32 Strikt genomen is Searle's theorie hier wat ingewikkelder (Searle spreekt van een 'double direction of fit'), maar dat is om te beginnen al niet zo'n aantrekkelijke visie en bovendien niet relevant voor de bespreking van rechtshandelingen.

33 Voor de theorievorming over regelgeving zijn de opdrachten ook van belang, al was het maar omdat sommige rechtsfilosofen ten onrechte regelgeving verwarden met het geven van opdrachten. Daarover meer in mijn eerdergenoemde artikel 'What is a norm?'.

34 Ruiter's Institutional Legal Facts geeft uitvoerige analyses van rechtshandelingen die in bepaalde opzichten dichter blijven bij Searle's originele onderscheidingen dan het hier gepresenteerde.

35 Speech Acts, 57 e.v.

36. Het valt te verdedigen dat zich bij een serieuze belofte twee bedoelingen voordoen. Ten eerste de bedoeling om een verplichting op zich te nemen en ten tweede de bedoeling om de aldus ontstane verplichting na te komen. Van deze twee bedoelingen is de eerste wezenlijk voor het verschijnsel beloven. Als de bedoeling om de belofte na te komen ontbreekt, is er nog steeds sprake 
van een belofte en brengt deze belofte de verplichting mee om het beloofde te doen. Omdat al tevoren de intentie aanwezig was om de belofte te breken, was de belofte niet serieus.

37 De volledige analyse van Searle (Speech Acts, 6o) is ingewikkelder, teneinde een aantal taalfilosofische complicaties te omzeilen. Deze complicaties en de door Searle gekozen weg om ze te omzeilen zijn hier niet relevant.

38 Geldig en ongeldig zijn categorieën die van toepassing zijn op regelgebaseerde activiteiten, activiteiten waarvoor regels gelden die aangeven hoe ze moeten worden verricht. (Zie ook de volgende paragraaf.) Als zo'n handeling volgens de regels wordt verricht is hij geldig; anders normaal gesproken ongeldig. Meer hierover in J.C. Hage, 'Enkele opmerkingen over geldigheid en gelding', Algemeen Nederlands Tijdschrift voor Wijsbegeerte 76 (1984), 262-266.

39 The Concept of Law, 93 e.v.

40 Voor een soortgelijke opvatting, maar dan specifiek over overeenkomsten, zie F. Terré,,Ph. Simler en Y. Lequette, Droit Civil- Les Obligations, ge druk, Parijs: Dalloz 2005, par. 28

41 Drie beginselen, 3. De gedachte dat er regels zijn die gedrag mogelijk maken vindt men reeds bij Rawls, Two concepts of rules, Philosophical Review 64 (1955), 3-32, Austin, How to do things with words, 14 e.v. en Searle, Speech Acts, 33 e.v.

42 Deze parallel met schaken is ontleend aan A. Ross, On Law and Justice, 11 e.v.

43 Om misverstanden te voorkomen: het niezen dient hier niet te worden geïnterpreteerd als een conventionele manier om de wil te uiten.

44 Dit brengt mee dat 'rechtshandelingen' gebaseerd op vertrouwen (art. 3:35 BW) geen echte rechtshandelingen zouden zijn. Daarover later meer.

45 Het is ook mogelijk om overeenkomsten enkel te zien als een belangrijke en veel voorkomende vorm van sociale interactie waaraan het recht rechtsgevolgen verbindt. Suggesties in deze richting zijn bijvoorbeeld te vinden in P.S. Atiyah, Essays on Contract. Oxford: Clarendon Press 1986, bijvoorbeeld op blz. 40 e.v. en Gilmore, The Death of Contract, Columbus: Ohio State University Press 1974, 87e.v. De nog te bespreken theorie van Van Dunné (normatieve toerekening) gaat ook in deze richting. Vanuit dit perspectief is het niet vanzelfsprekend dat de door partijen beoogde rechtsgevolgen inderdaad intreden. Of het wenselijk is dat die rechtsgevolgen intreden is vanuit dit perspectief een open vraag.

46 De logische aspecten van uitzonderingen op regels, zoals de regel dat contracten de door partijen beoogde rechtsgevolgen hebben, komen uitvoerig aan de orde in F. Schauer, Playing by the rules. Oxford: Clarendon Press 1991 en in Jaap C. Hage, Reasoning with Rules. Dordrecht: Kluwer 1997.

47 Het gaat hier om het verschil tussen het rechtvaardigen van een institutie (in casu die van de overeenkomst) en van toepassingen van de institutie (wat zijn de rechtsgevolgen van een concrete overeenkomst?). Dit onderscheid is benadrukt door John Rawls in zijn artikel Two concepts of rules.

48. Over Begriffsjurisprudenz, zie M. Marx, 'Systeme des 19. Jahrhunderts', in A. Kaufmann und W. Hassemer (red.) Einführung in Rechtsphilosophie und Rechtstheorie der Gegenwart, Heidelberg: Müller Juristischer Verlag 1977, 97-102 en K. Larenz, Methodenlehre der Rechtswissenschaft, 5e druk, Berlin: Springer Verlag 1983, $19 f$. 
49 Deze thematiek, maar dan toegespitst op één bepaald soort rechtshandeling, namelijk de overeenkomst, heeft een centrale plaats in Gilmore's The Death of Contract.

50 Van Dunné, Normatieve uitleg, 198.

51 Van Dunné erkent dit ook. Zie Normatieve uitleg, 269 e.v.

52 In Nederland is dat neergelegd in art. 3:35 BW. In Duitsland geldt een vergelijkbare regeling op grond van art. 119 BGB.

53 Deze aanpak wordt bijvoorbeeld gekozen in artikel 2:102 van de Principles of European Contract Law, dat luidt: 'The intention of a party to be legally bound by contract is to be determined from the party's statement or conduct as they were reasonably understood by the other party.' (Cursivering toegevoegd.)

54 Afdeling 6.5.3 van het BW zou bij de voorgestane constructie dan ook geen uitzondering meer te hoeven zijn op de algemene regeling van het contractenrecht.

55 De in dit verband in de common law gebruike uitdrukking 'implied terms' is daarom wel bijzonder ongelukkig. Het betreft juist geen 'terms' maar enkel normen die door het recht worden verbonden aan het bestaan van een bepaald soort contract.

56 Net zoals er verbintenissen naar aanleiding van een overeenkomst kunnen ontstaan, kunnen er ook rechtsplichten naar aanleiding van een overeenkomst ontstaan, waarvan de schending een onrechtmatige gedraging oplevert. De zogenaamde 'derdenwerking' van overeenkomsten kan hiermee worden verklaard. Het zal duidelijk zijn dat deze 'derdenwerking' in het geheel geen inbreuk maakt op het beginsel dat overeenkomsten slechts partijen binden. De derden worden gebonden door het recht, naar aanleiding van het bestaan van een overeenkomst.

57 Dat blijkt bijvoorbeeld uit de artikelen 2:104 en 2:209 van de Principles of European Contract Law en de 'contra preferentem' regel voor de interpretatie van met name standaardbepalingen uit contracten. Vgl. H. Beale, A. Hartkamp, K. Kötz en D. Tallon, Cases, Materials and Text on Contract Law, Oxford: Hart 2002, 568 e.v.

58. Dit werd aanvaard in het bekende arrest Quint/Te Poel (HR 30 januari 1959, NJ 1959, 548) en neergelegd in art. 6:1 BW.

59. Vgl. de conclusie van Bloembergen in het arrest HR 26 januari 1990, NJ 1990, 794.

60 In dit verband is het belangrijker dat de betreffende regels deze werking hebben, dan dat ze expliciet zo luiden. Als in de formulering van een regel die aangeeft wat geldt als rechtshandeling niet wordt verwezen naar de intentie om rechtsgevolgen in het leven te roepen, maar naar het gerechtvaardigde vertrouwen dat zo'n intentie aanwezig was, dan zal die regel in grote lijnen net zo functioneren als een regel die wel expliciet verwijst naar de intentie. Dat is voldoende voor het bestaan van het instituut rechtshandeling, al roept het vragen op over de wijze waarop de rechtshandeling is geregeld.

61 Met dank aan Gerrit van Maanen, Petra van Spronsen en de deelnemers van het door Jan Smits georganiseerde Maastrichtse seminar over het Europese ius commune, voor nuttige opmerkingen naar aanleiding van eerdere versies van deze rede. 